\title{
Ethnocentrism - the danger of cultures' collision
}

\author{
PhD. Traian-Alexandru MIU \\ Faculty of Theology and Sciences of Education, \\ „Valahia” University of Târgoviște, \\ ROMANIA \\ E-mail: traianalexandrumiu@gmail.com
}

\begin{abstract}
In the context of the globalization, the contact between different cultures and religions has reopened a number of problems. Thus, one of the current challenges is the ethnocentrism. This anthropological and ethnological concept involves an overestimation of national, religious, racial, geographic group to which we belong, and an understatement of other groups, that because of prejudice about other people. The ethnocentrism may lead us to chauvinism, xenophobia and racism! The globalization facilitates the rapid encounter between different cultures and, thus, it is developing the tendency that one to consider being superior to another. Thus are being born the ethnocentric tendencies. We can say that ethnocentrism is a 'prodrug' of globalization, providing support and arguments for perpetuating this process.
\end{abstract} Keywords: ethnocentrism, globalization, culture, religion, multiculturalism.

\section{INTRODUCTION}

The globalization, phenomenon with multiple implications for human society, has opened many effects, both positive and negative. Migration, encouraged today by the access to better jobs and living conditions superior to other generations, by the opening of state borders, by rapid transmission of information, etc., facilitated the contact between different cultures and religions, reopening a number of problems. In this context, the emigration of a increasing number of people, a thing noticeable worldwide, and to a lower level, if we refer to Europe, and especially to the structure of economic policy that today is called "the European Union", it is suitable approaching the issue related to ethnocentrism and globalization, especially because globalization has facilitated the manifestation of the ethnocentric phenomenon.

\section{The ethnocentrism}

Ethnological and anthropological concept, which was introduced in 1907 by William Graham Sumner in his book Folkways, the „ethnocentrism is the technical name for this view of things by which one's own group is the centre of everything, and all the others are scaled and rated with reference to it."[1]

The ethnocentrism reveals the tendency to privilege the norms and traditions of our own society to the detriment of other societies, in other words their own culture is considered to be superior to all other cultures.[2] This implies an overestimation of national, religious, racial, geographic group, to which we belongs, and an underestimation of other groups, that because of prejudice regarding other people. In its aggravated form, the ethnocentrism can be fully found in the racist thinking. The opposite of the ethnocentrism is the xenocentrism. The xenocentrism is also based on certain prejudices such as that to appreciate everything 
foreign as good automatically. The xenocentrism consists in underestimating of the specific cultural values of their own nation and the overestimation of the cultural values of others.

The ethnocentrism makes its presence felt when you judge others according to your own cultural references. Therefore, the ethnocentrism may lead us to chauvinism, xenophobia and racism. Also, it can easily get to colonialism when consider we have the mission to civilize other peoples, and even to imperialism, when we think we have the right to subjugate them. Let us not forget that such things have happened in the past with the discovery of Africa and America. The Spanish, Portuguese, English, French etc. explorers / the conquistadores, have shown towards local population ethnocentric behavior taken to extremes, therefore to imperialism.

The most famous example of what can entail ethnocentrism, as a movement that overestimates their cultural and ethnic values, is the Nazi doctrine. The Nazis developed the idea that the Aryan race is superior to all existing breeds on earth, that's why the Jews and the Gypsies were considered inferior in terms of race. What resulted was reached due to this Nazi ethnocentrism, it is well known. It seems that Hitler has built the doctrine of Aryan superiority on the philosophy of Nietzsche, but was based on the scientific theory of evolution proposed by Charles Darwin. To understand the way in which Darwin judge things, here's an excerpt from one of his books, in which characterized the fuegians, inhabitants of the Land of Fire: "These poor creatures wore all the signs of degeneration, their cheeks were hideous, smeared with white, dirty and greasy skin, hair tangled, broken voice and gesticulating violently. Seeing such people, hardly somebody thinks that they are our fellows, inhabitants of the same planet (...) they need the imagination to evoke, rationality to compare and judgment to discriminate? To detach Patelle [3] off the cliff does not require not even slyness, the lower faculty of mind. Their skill in some aspects can be compared to animal instinct (...) (Ch. Darwin, Travel around the world aboard the ship Beagle)" [4].

Of course, the characteristics of the people described by Darwin not made them "less people" than his fellow countrymen who had different clothing and food habits that distinguished them from other cultures, and these particularities did not mean at all that there are "signs of degeneration".

All to understand better what generated this non-acceptance of differences in culture and race, taken to the extreme, so to the point that those who are different were not considered human beings, I will quote a note from the diary of the scientist Emil Racoviţă, dated December 10, 1897: "The Indians tell that whites are cannibals, they eat their babies. Apparently did not lie. The priest says that some British gold miners killed and ate an Indian out of curiosity. (Emil Racoviță, Jurnal, edited by Al. Marinescu, Anca Bănărăscu and Al. Iftime, Ed. Compania, 1999, p. 74)'"[5].

Here's how sometimes science support, and other times the lack of knowledge has led to the suppression of countless lives. That is why we should carefully review every concept that can influence human life at the micro or macro level, as does that of the ethnocentrism concept, to determine the positives and negatives aspects.

\section{The ethnocentrism versus the globalization}

The globalization, phenomenon of a great complexity, create links, spaces, integration and transnational interdependence in the economic, social, cultural, political, technological and environmental spheres. 
The problems that the globalization creates, come from the fact that what is looming as a result of them is a certain world domination which does not account for the diversity of the nations, disregards the countries, the companies and the individuals only insofar as they serve the purposes outlined, so only if they enhance the benefits of an economy which is controlled systematically to be useful only to those who draws his guidelines. Therefore, fears about the consequences that will bring this phenomenon is that a possible predominance of them "could lead to the destruction of the human person and the end of history and the various forms of culture and civilization"[6].

In this case, what interests us about the globalization is the cultural sphere that she possesses. It can be seen, easily, the fact that there has been a development of cultural communication in the world, everything urging to a new consciousness and cultural identity, which is easily achievable thanks to access to new cultural ideas and products, but also to the increased consumption thereof. These things are facilitated by adoption of the new technical means and the various practices.

Globalization has opened its doors to multiculturalism and those of the individual access in everything related to cultural diversity.

It may refer in a reduction in global diversity or even because of the cultural hybridization, or due to assimilation. Creating a global culture would be possible only when the particular cultures would lose importance, and at the same time, the ethnic identity of various peoples would no longer count. Therefore, for the establishment of a global culture of major importance is the ethnic aspect of the globalization phenomenon, he assuming a different form of migration of particular cultural values worldwide. We can talk about a "transnationalization" of the culture. This is facilitated by its outstanding technological progress, but also by the easy migration of the peoples, each carrying with them the cultural specificity. This is also evidenced by the symbols used by people in cyberspace. In fact, what we now call global culture is nothing more than a type of culture adapted to the problems which the globalization generated. Such culture is characterized by: universalism, eclecticism, timelessness and technicism. National cultures differ from global culture through temporality, expressiveness and particularism, characteristics that led to the continuity of the various human communities.[7]

Culture, the nucleus and the origin of ethnic, and to a certain extent also of the ethnocentrism, is in open conflict with globalization changes manifested to the economic, social and political level. As globalization facilitates rapid encounter between different cultures, there is a tendency to believe that one is superior to another. This creates ethnocentric tendencies. We can say that the ethnocentrism is a 'pro drug' of globalization, providing support and arguments for perpetuating this process. This has been possible because of the desire to dominate, to be the first, which manifests the person or group when they consider that it has a higher military force, economic and cultural level. Moreover, it is demonstrated that the most effective domination it is achieved through culture.[8]

„The migrations and the commerce were able to impose some groups on others by conquering territories, populations, markets or economic sectors, countries or regions, through tactical and strategic arguments. But these are not anything other than cultural and civilization results. Military, political and, of course, cultural expansions preceding the World War II are placed under the umbrella of globalization ("emblematic examples of globalization"), glancing at the origin that were are all manifestations of ethnocentrism. And, implicitly, of a particular type of manifestation of the cultural, even if we were forced to associate such negative connotations to that concept (culture).'[9] 
The ethnocentrism and the globalization have similarities, but also some points that differentiate them. The ethnocentrism is individualized to globalization by the fact that it preserves ethnic and cultural specificity and, at the same time, is trying to impose, through various methods (persuasion, aggression etc.), those in contact with, be it countries, regions, ethnic groups etc. Instead, globalization is unable to increase the coverage area of social, cultural, economic, political, than by integration.[10]

Compared to the ethnocentrism, which brings into question just the cultural supremacy, the globalization include it, but adds (in competition which aims conquest of territories for possession and exploitation of raw materials and cheap labor force), the economic progress. Moreover, new forms of movement of capital have made the economic courts to "dig deep" in order to subvert the ones of the State, giving rise to so-called "multinational corporations". Thus, nation-states have no longer the control over the investment decisions, requiring a review of the role which they once had.

\section{Ethnocentrism and religion}

I mentioned at the beginning of this article about the ethnocentrism taken to an extreme, i.e. about the imperialism, and I said that this is not a strange history of human society. It was the case of meeting different cultures and religions during the great expeditions of exploration and conquest initiated from the European continent. Most often under the pretext of possession the truth of faith, of a higher culture and civilization, local populations were decimated. To understand the error into which the conquistadors fell, and where we can fall today, the German sociologist Ulrich Beck writes: "A caricature shows us how the Spanish Conquistadors have stepped into the new world in the glow of their weapons. "We come to you", it is written in the bulla "to talk to you about God, civilization and truth". A group of locals amazed responds: "Of course, what you want to know?" How has happened and is happening the blood baths which followed, it has been frequently described without any consequences. What is the comical of the scene? Ridiculousness of the scene result from the mutual misunderstanding of the meaning of this "meeting": ultraarmed Western imperialism conceals its missionary zeal behind empty talk about "intercultural dialogue". While locals understand the situation wrongly and naive as an offer of dialogue, desiring to communicate, although they will be stuffed with foreign certainties, then be butchered like Christmas geese."[11]

Exposing this caricature, Beck highlights the tragedy that followed the failed intercultural dialogue. The ethnic identity of a people cannot be part of any ranking, cannot be considered inferior or superior to another. Of course, the conquistadors intended to preach the Gospel among those who had not had still any contact with Christianity, but the way they have done for the purpose can be achieved has caused countless bloodshed and destruction. This was due to "blind potting perception of what is foreign in their own certainties"[12].

The Orthodoxy has avoided, mostly, Westerners mistakes, always relying on dialogue, which facilitated inculturation, namely the transmission of evangelical principles within the particular cultures, always taking into account to their specific features. The ethnic specific of peoples who had received "The Good News" was always kept; this was part of the specific mission of the Orthodox Church. It arose in the Orthodox world the socalled 'unity in diversity' encountered in the local Churches that have preserved the specific cultural traditions, but at the same time, they have preserved also the unity of faith. For example, the identity of Orthodox peoples (such as the Greek, Russian, Romanian, and Bulgarian) was preserved; however, the unity of faith was not impaired. 
Instead of conclusions, I want to bring attention to what asserted, not too long ago, the famous anthropologist and the ethnologist Claude Lévi-Strauss (1908-2009): "Cultures are creative when they are not isolated greatly, but it requires some insulation. In every civilization there is an optimum of openness and closure, between isolation and communication, which corresponds to the most fertile periods of their history. If the cultures are not communicating, they get sick, but they should not communicate too quickly to have time to assimilate what they borrow from abroad. Today I feel that Japan is the only country that has achieved this optimal: it absorbs more from the outside and refuses more" [13].

\section{REFERENCES}

[1] William Graham Sumner (1959 [1907]), Folkways: A Study of Mores, Manners, Customs and Morals (NewYork: Dover Publications, 1959 [1907]), 13, apud Sonia Catrina, „Social Categorization as a Manner of Creating Boundaries, Avoiding and Discriminating against the ,Other(s)”, in Sfera Politicii, nr. 2 (168)/2012, p.6;

[2] Ibidem, p. 7;

[3] Patelle = word that designate different species of gastropods (mollusks).

[4] Oana Iftime, Introducere în antievoluționismul științific: despre evoluția omului de către om, Ed. Anastasia, București, 2003, p. 29;

[5] Ibidem, p. 31;

[6] Georgios I. Mantzaridis, Globalizare și universalitate: himeră şi adevăr, trans. Pr. prof. dr. Vasile Răducă, Ed. Bizantină, București, 2002, p.21;

[7] Pr. prof. univ. dr. Emil Dumea, „Religie și valori în era globalizării”, Dialog teologic, nr. 27/2011, p. 58;

[8] Dumitru Zaiț, „Globalizare și etnocentrism”, in Management intercultural, vol. III, nr. 4, 2001, p. 3, col 1;

[9] Ibidem, p. 4, col. 1-2;

[10] Ibidem, p. 5, col. 1-2;

[11] Ulrich Beck, Ce este globalizarea? Erori ale globalismului - răspunsuri la globalizare, trad. Ida Alexandrescu, Diana Popescu, Ed. Trei, București, 2003, pp. 107-108;

[12] Ibidem, p. 108;

[13] «Claude Lévi-Strauss, l'explorateur de la nature humaine», entretien avec Guy Sorman, Figaro Magazine, 3 septembre 1988, apud Jacques Marlaud, „Claude Lévi-Strauss méconnu”, web: http://www.espriteuropeen.fr/portraits_levistrauss.html 